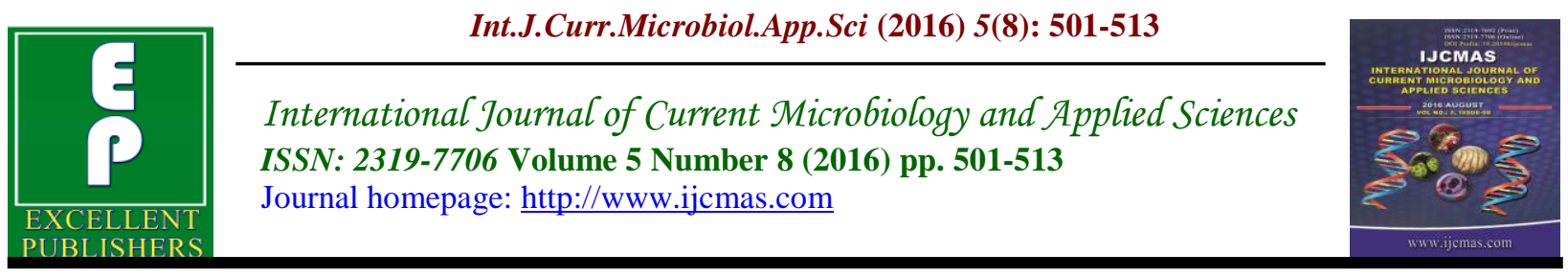

Original Research Article

http://dx.doi.org/10.20546/ijcmas.2016.508.054

\title{
Antagonism of Bacillus thuringiensis NCIM2130 against Sclerotium rolfsii Sacc., A Stem Rot Pathogen of Groundnut
}

\author{
Ravindra Raosaheb Rakh ${ }^{1 *}$ and Sanjay Marotrao Dalvi ${ }^{2}$ \\ ${ }^{1}$ Department of Microbiology, Shri Guru Buddhiswami Mahavidyalaya Purna (Jn.), India \\ ${ }^{2}$ Department of Botany, Shri Guru Buddhiswami Mahavidyalaya Purna (Jn.), India
}

*Corresponding author

\begin{tabular}{|c|c|}
\hline & A B S T R A C T \\
\hline Keywords & \multirow{4}{*}{$\begin{array}{l}\text { Stem rot is one of the most drastic diseases of groundnut that cause major crop loss. } \\
\text { Stem rot pathogen of groundnut, Sclerotium rolfsii, was isolated from the infected } \\
\text { groundnut stem. Present investigation was started to search for effective biocontrol } \\
\text { agent against Sclerotium rolfsii. To find effective biocontrol agent, } 120 \text { Bacillus } \\
\text { spp. isolated from various rhizospheric soils of healthy plants, screened in vitro } \\
\text { against the stem rot pathogen by dual culture technique. Out of these Bacillus spp, } \\
\text { Bacillus } 57 \text { isolate found effective in controlling the phytopathogen by Novel Ring } \\
\text { method ( } 80.21 \%) \text {. Bacillus } 57 \text { was identified by } 16 \mathrm{~S} \text { rRNA sequencing as Bacillus } \\
\text { thuringiensis NCIM } 2130 \text {. To effectively control the phytopathogen in vitro, the } \\
\text { Bacillus thuringiensis NCIM } 2130 \text { produced the Volatile metabolites, and } \\
\text { Siderophore. }\end{array}$} \\
\hline $\begin{array}{l}\text { Stem rot, } \\
\text { Sclerotium rolfsii, } \\
\text { Bacillus } \\
\text { thuringiensis } \\
\text { NCIM2130, } \\
\text { Siderophore. }\end{array}$ & \\
\hline Article Info & \\
\hline $\begin{array}{l}\text { Accepted: } \\
23 \text { July } 2016 \\
\text { Available Online: } \\
10 \text { August } 2016\end{array}$ & \\
\hline
\end{tabular}

\section{Introduction}

Modern Agriculture heavily relies on the application of chemical pesticides for disease control. Due to the concerns regarding human health and environmental issues, an alternative to these chemicals pesticides being searched (Franks et al., 2006). The use of biological control approach against phytopathogens to replace hazardous effect of chemical pesticides on fertilizing soils is steadily gaining worldwide acceptance. In this regard, the use of plant growth promoting rhizobacteria (PGPR) has proven potential in developing sustainable agricultural systems for crop production and protection (Erturk et al., 2010; Govindasamy et al., 2011). Among the genera of bacteria, Bacillus spp., Pseudomonas spp. is widely used as biocontrol agents and Bacillus spp. has been reported to produce several antibiotics (Ferreira et al., 1991).

Several studies reveal that Bacillus species are among the most prominent bacteria found to colonize plants root and soil populations (Beneduzi et al., 2008). The genus Bacillus is characterized by Gram positive, aerobic or facultative anaerobic, rod shaped bacteria that form endospores 
(Clausand Berkeley, 1986). Bacillus species protect plants against pathogens by direct antagonistic interactions between the biocontrol agent and the pathogen, as well as, by induction of host resistance. It largely depends on a wide variety of traits, such as the production of structurally diverse antibiotics (Liu et al., 2006), production of iron chelators, bacterial phytohormones and/or the solubilization of mineral phosphates(Calvo et al., 2010; Viruel et al., 2011) and a ubiquitous presence in soil (Gajbhiye et al., 2010). Enhancement of plant growth by root colonizing Bacillus sp. is well documented (Kloepper et al., 2004; Idris et al., 2007a; Idris et al., 2007b).

In India among the soil-borne fungal diseases of groundnut, stem rot caused by $S$. rolfsii is a potential threat to production and is of considerable economic significance for groundnut grown under irrigated conditions. Stem-rot caused by $S$. rolfsii is sporadic in most of the groundnut growing areas like Tamil Nadu, Andhra Pradesh, and Karnataka (Pande and Narayana, 2000). The traditional agricultural practice to control the phytopathogen $S$. rolfsii is by using variety of fungicides e.g. Bavistin, Captan etc. but a severe disadvantage of the traditional method, that it is not effective to check the Sclerotium during the cropping duration (90100 days) and is not eco-friendly. Hence, as an alternative attempt has been made to give an eco-friendly strategy for the control of Sclerotium during this work.

Keeping in view, the importance of rhizospheric bacteria in sustainable agriculture development by controlling the phytopathogen, the present study aims at (i) Isolation of stem rot causing pathogen of Groundnut, (ii) Screening of Bacillus isolates isolated from rhizospheric soil for in vitro antagonism against Sclerotium rolfsii (iii) To identify the bacillus isolate based on
16S rRNA sequencing and (iv) Characterization of in vitro biocontrol mechanism of Bacillus isolates.

\section{Materials and Methods}

\section{Collection of diseased groundnut plants}

Diseased groundnut stems were collected from Adgaon fields near the Purna in polyethylene bags and brought to laboratory, Department of Microbiology, Shri Guru Buddhiswami Mahavidyalaya, Purna (Jn.) Parbhani (Maharashtra) (Photo Plate 1).

\section{Isolation of Phytopathogen}

Diseased groundnut stem showing typical symptoms of stem rot i.e. wilting of total plants, white mycelial growth at collar region of plant (Photo Plate 1) were selected and used as source for the isolation of causative agent. Infected portion of stem was cut into small pieces with sterilized scalpel, cleaned with distilled water, then surface sterilized with $0.1 \% \mathrm{HgCl}_{2}$ solution for 30 second and again washed thrice with sterile distilled water. Small 1 to 2 pieces were transferred aseptically on Potato Dextrose Agar (PDA) plates containing Chloramphenicol $(30 \mathrm{mg} / 100 \mathrm{ml})$ with the help of sterilized forceps under aseptic condition (Rakh, 2010). Inoculated Petri plates were incubated at $25^{\circ} \mathrm{C}$ for 7 days for growth of the pathogen.

\section{Isolation of Rhizobacteria}

To isolate rhizospheric Bacillus, soil from different healthy plants such as neem, soybean, tur and groundnut were collected in poly-ethylene bags and brought to the research laboratory. $1 \mathrm{gm}$ of soil sample was inoculated into $100 \mathrm{ml}$ nutrient broth and kept for incubation at room temperature for $24 \mathrm{~h}$. For isolation of Bacillus isolates, 
modified method of (Kim et al., 1997) was employed. $1 \mathrm{ml}$ of enriched Nutrient Broth was added to $10 \mathrm{ml}$ sterile distilled water and kept at $80^{\circ} \mathrm{C}$ for $20 \mathrm{~min}$. later on a loopful of culture was streaked on nutrient agar plates and incubated at room temperature for $48 \mathrm{hr}$. After incubation, typical white colonies were picked up individually and purified on nutrient agar slants. All the isolates were tentatively named during this research to avoid confusion.

\section{Screening for Potential Biocontrol agents}

For primary screening, all the Bacillus isolates were screened for potential antagonistic activity against $S$. rolfsii, on King's B agar (Ran et al., 2003) by using dual culture technique (Rangeshwaran and Prasad, 2000). An agar disc (5 mm) was cut from an actively growing (96 h) S. rolfsii, and placed on the surface of fresh King's B Agar medium at the one side of the Petri plates. A loopful of actively growing Bacillus isolates (each) was placed opposite to the fungal disc. Plates inoculated with phytopathogen and without bacteria were used as control. Each experiment was carried out in triplicates. Plates were incubated at room temperature for 7 days. Degree of antagonism was determined by measuring the radial growth of pathogen with bacterial culture and control and Percent inhibition was calculated by the following equation (Riungu et al., 2008).

In secondary screening, efficient antagonistic Bacillus isolate was tested for biocontrol activity against Sclerotium rolfsii by Novel ring method (Adetuyiand Cartwright, 1985; Agarry et al., 2005). A 5 $\mathrm{mm}$ diameter mycelial disc of the fungal pathogen was inoculated at the centre of a 9 $\mathrm{cm}$ diameter Petri plate containing king's B agar and the bacterial isolate was streaked at a distance of $2-3 \mathrm{~cm}$ from the centre in a circular pattern. The control plates were inoculated only with the fungal pathogens. The plates were incubated at $28^{\circ} \mathrm{C}$ and checked daily until the fungal growth on the control plate (inoculated only with $S$. rolfsii) reached the edge of the plate. Each experiment was carried out in triplicates. Percent inhibition was calculated by the following equation (Riungu et al., 2008).

Inhibition $(\%)=$

Colony diameter of pathogen - Colony

diameter of pathogen + alone (Control)

Antagonist

Colony diameter of pathogen alone

Efficient antagonistic Bacillus isolates were identified by using $16 \mathrm{~S}$ rRNA sequencing. $16 \mathrm{~S}$ rRNA sequencing of culture was carried out at Agharkar Research Institute (ARI) Pune, Maharashtra.

\section{Characterization of Biocontrol Mechanism}

To characterize the mechanism of biocontrol agent, the efficient Bacillus isolate tested for the production of volatile metabolite, and siderophore.

\section{Detection of volatile metabolites}

For detection of volatile antifungal metabolites produced by the Bacillus isolate, two half plates (sterile) were taken. The plates were poured with sterile molten and cooled King's B Agar and allowed to solidify. Now the Bacillus isolate was inoculated on one of the half plate in centre and on the other half the four day old pure culture of fungal phytopathogen was placed. Both half plates were placed face to face preventing any physical contact between the pathogen and the bacterial suspension. The plates were sealed to isolate the inside 
atmosphere and to prevent loss of volatiles produced. Plates were incubated at room temperature for 6 days and the growth of the pathogen was measured and compared to control plates developed in the absence of the bioantagonist. Experiment was run in triplicate (Montealegro et al., 2003). Results are expressed as means of inhibition (\%) of the growth of fungal pathogens in the presence and absence of any bacterial isolate. Percent inhibition was calculated using the following formula (Montealegro et al., 2003).

Percent Inhibition $=\frac{100(\mathrm{C}-\mathrm{T})}{\mathrm{C}}$

Where,

$\mathrm{C}=$ Radial growth of fungus in control plates (mm).

$\mathrm{T}=$ Radial growth of fungus on the plate inoculated with Antagonist (mm).

\section{Qualitative Detection of Siderophore}

Qualitative detection of siderophore was carried out by using modified CAS - blue agar(Adriane et al., 1999). CAS-blue agar (1 1) was prepared according to (Schwyn and Neilands, 1997) using $60.5 \mathrm{mg}$ CAS dissolved in $50 \mathrm{ml}$ water distilled, deionized, and mixed with $10 \mathrm{ml}$ iron (III) solution (1 $\mathrm{mM} \mathrm{FeCl} .6 \mathrm{H} 0,10 \mathrm{mM} \mathrm{HCl})$. Under stirring, this solution was slowly added to $72.9 \mathrm{mg}$ HDTMA dissolved in $40 \mathrm{ml}$ water. The resultant dark blue liquid was autoclaved at $121^{\circ} \mathrm{C}$ for $15 \mathrm{~min}$. Also autoclaved was a mixture of $750 \mathrm{ml}$ water, $15 \mathrm{~g}$ agar, $30.24 \mathrm{~g}$ Pipes, and $12 \mathrm{~g}$ of solution of $50 \%(\mathrm{w} / \mathrm{w}) \mathrm{NaOH}$ to raise the $\mathrm{pH}$ to the $\mathrm{pKa}$ of Pipes (6.8). The dye solution was finally poured along the glass wall and agitated with enough care to avoid foaming.

Petri dishes $(10 \mathrm{~cm}$ in diameter $)$ were prepared with $30 \mathrm{ml}$ of king's B medium for culturing. After becoming solid, the medium was cut into halves, one of which was replaced by CAS - blue agar $(15 \mathrm{ml})$. The halves containing culture medium were inoculated with strains taken from stock cultures. The inoculum was placed as far as possible from the borderline between the two media. The plates were incubated at growth temperature of each strain for seven day in the dark. Strain growth rates were daily monitored and expressed as the number of days required by the microorganism mycelia to cover the halves of Petri plates containing the culture medium. The CAS reaction rate was determined by measuring the advance of the color - change front the CAS - blue agar, starting from the borderline between the media. The CAS agar color changed from blue to orange, purple, or dark purplish - red (Adriane et al., 1999).

\section{Result and Discussion}

\section{Isolation of Sclerotium rolfsii}

After 7 days incubation on PDA plates, the fungus produced abundant white septate mycelia, 1.5-3.0 $\mu \mathrm{m}$ diameter with clamp connections at each septation, aerial hyphae and also numerous spherical, or ellipsoidal, white sclerotia, 0.5-2.0 $\mathrm{mm}$ diameter, which turned brown on maturation, (Photo Plate 2). Based on morphological and culture characteristic, the disease causing organism was identified as Sclerotium rolfsii (Mesquita et al., 2007).

\section{Isolation of Rhizobacteria}

During present research work, 120 rhizospheric Bacillus isolates were isolated from rhizospheric soil of different healthy plants such as Soybean, Neem, Tur etc. All the rhizospheric Bacillus isolates were tentatively named as Bacillus 1 to 120 . 
Screening for Biocontrol agents against Phytopathogens

The entire 120 Bacillus isolates were primarily screened for their antagonistic activity against isolated pathogen of groundnut viz. S. rolfsii, by dual culture technique which later on secondarily tested by Novel rings method. The present investigation reveals that among the 120 isolates, the Bacillus isolates namely Bacillus 57 found as efficient antagonists against $S$. rolfsii during primary screening (79.35\%) while comparing to other Bacillus isolates (Table 1). Other Bacillus isolates also showed considerable inhibition of Sclerotium rolfsii in vitro but not as efficient as Bacillus 57.The Bacillus 57 secreted antifungal compound which was antagonistic and inhibited Sclerotium rolfsii growth $80.21 \%$ in vitro in comparison to control and with absence of sclerotial production, during the secondary testing (as shown in Photo Plate 3 and Table 2). The 16 S rRNA gene sequencing of the Bacillus 57 revealed as Bacillus thuringiensis NCIM2130.

Our results were also supported by other researcher's work where Bacillus spp. used as biocontrol agent for various disease causing pathogens affecting different plant (Killani et al., 2011; Karimi et al., 2012)B. subtilis reported to reduce the growth of S. rolfsii effectively on PDA when compared with the control(Helena and Ferreira,1988). This reduction in growth suggests that fungistatic material was produced by $B$. subtilis on PDA. Bacillus subtilisfound effectively in controlling Sclerotium rolfsii by producing bioactive compound (Gomashe et al., 2014).

In Vitro studies showed that B. subtilis strain, EPCO 16 showed greatest per cent inhibition (44.4) than other two strains tested on the sugarbeet root rot pathogen, $S$. rolfsii (Thilagavathi et al., 2014).An inhibitory effect of Bacillus on wide range of fungi including $S$. rolfsii was documented by several researchers (Nalisha et al., 2006; Wahyudi et al., 2011). The results obtained by us was fare better than the results shown by these studies where Sclerotium rolfsii was inhibited in vitro by Bacillus thuringiensis NCIM2130 (80.21\%).

\section{Characterization of Biocontrol Mechanism}

To characterize the biocontrol mechanism, Bacillus thuringiensis NCIM2130 tested for

\section{Detection of Volatile Metabolites}

Bacillus thuringiensis NCIM2130 produced volatile metabolites in vitro which inhibited the growth of Sclerotium rolfsii upto $20 \%$ as shown in Photo plate 4.

Table.1 Primary Screening of Bacillus isolates against Sclerotium rolfsii by dual culture technique

\begin{tabular}{|c|c|c|c|c|c|}
\hline 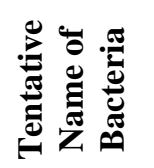 & 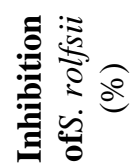 & 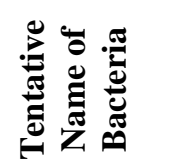 & 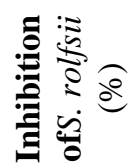 & 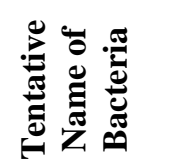 & 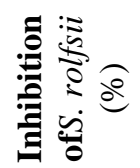 \\
\hline Bacillus 1 & 21.2 & Bacillus 52 & 12.0 & Bacillus 103 & 0.0 \\
\hline Bacillus 2 & 35.3 & Bacillus 53 & 19.8 & Bacillus 104 & 16.8 \\
\hline Bacillus 3 & 43.1 & Bacillus 54 & 13.1 & Bacillus 105 & 0.0 \\
\hline Bacillus 4 & 12.1 & Bacillus 55 & 25.8 & Bacillus 106 & 35.2 \\
\hline Bacillus 5 & 21.0 & Bacillus 56 & 8.7 & Bacillus 107 & 18.6 \\
\hline
\end{tabular}


Int.J.Curr.Microbiol.App.Sci (2016) 5(8): $501-513$

\begin{tabular}{|c|c|c|c|c|c|}
\hline Bacillus 6 & 30.4 & Bacillus 57 & 79.35 & Bacillus 108 & 41.5 \\
\hline Bacillus 7 & 19.0 & Bacillus 58 & 5.8 & Bacillus 109 & 4.2 \\
\hline Bacillus 8 & 12.5 & Bacillus 59 & 13.2 & Bacillus 110 & 0.0 \\
\hline Bacillus 9 & 21.4 & Bacillus 60 & 28.1 & Bacillus 111 & 47.9 \\
\hline Bacillus 10 & 16.9 & Bacillus 61 & 33.7 & Bacillus 112 & 37.8 \\
\hline Bacillus 11 & 31.7 & Bacillus 62 & 10.3 & Bacillus 113 & 0.0 \\
\hline Bacillus 12 & 33.0 & Bacillus 63 & 35.2 & Bacillus 114 & 17.4 \\
\hline Bacillus 13 & 27.0 & Bacillus 64 & 41.7 & Bacillus 115 & 19.3 \\
\hline Bacillus 14 & 36.4 & Bacillus 65 & 31.6 & Bacillus 116 & 28.4 \\
\hline Bacillus 15 & 20.2 & Bacillus 66 & 46.8 & Bacillus 117 & 27.6 \\
\hline Bacillus 16 & 16.0 & Bacillus 67 & 32.8 & Bacillus 118 & 0.0 \\
\hline Bacillus 17 & 11.0 & Bacillus 68 & 15.6 & Bacillus 119 & 19.7 \\
\hline Bacillus 18 & 14.0 & Bacillus 69 & 14.6 & Bacillus 120 & 43.7 \\
\hline Bacillus 19 & 23.0 & Bacillus 70 & 27.3 & & \\
\hline Bacillus 20 & 26.9 & Bacillus 71 & 45.8 & & \\
\hline Bacillus 21 & 25.0 & Bacillus 72 & 41.5 & & \\
\hline Bacillus 22 & 18.7 & Bacillus 73 & 37.4 & & \\
\hline Bacillus 23 & 13.4 & Bacillus 74 & 48.2 & & \\
\hline Bacillus 24 & 15.7 & Bacillus 75 & 26.4 & & \\
\hline Bacillus 25 & 25.0 & Bacillus 76 & 35.8 & & \\
\hline Bacillus 26 & 13.8 & Bacillus 77 & 11.5 & & \\
\hline Bacillus 27 & 26.5 & Bacillus 78 & 23.4 & & \\
\hline Bacillus 28 & 34.2 & Bacillus 79 & 14.7 & & \\
\hline Bacillus 29 & 11.8 & Bacillus 80 & 21.7 & & \\
\hline Bacillus 30 & 14.3 & Bacillus 81 & 29.0 & & \\
\hline Bacillus 31 & 31.1 & Bacillus 82 & 15.2 & & \\
\hline Bacillus 32 & 25.1 & Bacillus 83 & 19.4 & & \\
\hline Bacillus 33 & 21.9 & Bacillus 84 & 23.9 & & \\
\hline Bacillus 34 & 23.2 & Bacillus 85 & 31.4 & & \\
\hline Bacillus 35 & 38.3 & Bacillus 86 & 46.3 & & \\
\hline Bacillus 36 & 27.4 & Bacillus 87 & $42 . .6$ & & \\
\hline Bacillus 37 & 11.3 & Bacillus 88 & 24.2 & & \\
\hline Bacillus 38 & 24.8 & Bacillus 89 & 33.1 & & \\
\hline Bacillus 39 & 9.8 & Bacillus 90 & 43.2 & & \\
\hline Bacillus 40 & 17.3 & Bacillus 91 & 41.2 & & \\
\hline Bacillus 41 & 23.1 & Bacillus 92 & 36.5 & & \\
\hline Bacillus 42 & 25.3 & Bacillus 93 & 39.2 & & \\
\hline Bacillus 43 & 13.1 & Bacillus 94 & 14.2 & & \\
\hline Bacillus 44 & 29.4 & Bacillus 95 & 23.6 & & \\
\hline Bacillus 45 & 21.8 & Bacillus 96 & 45.8 & & \\
\hline Bacillus 46 & 10.9 & Bacillus 97 & 34.7 & & \\
\hline Bacillus 47 & 16.1 & Bacillus 98 & 11.5 & & \\
\hline Bacillus 48 & 20.5 & Bacillus 99 & 5.3 & & \\
\hline Bacillus 49 & 21.5 & Bacillus 100 & 3.0 & & \\
\hline Bacillus 50 & 32.1 & Bacillus 101 & 0.0 & & \\
\hline Bacillus 51 & 23.1 & Bacillus 102 & 37.5 & & \\
\hline
\end{tabular}



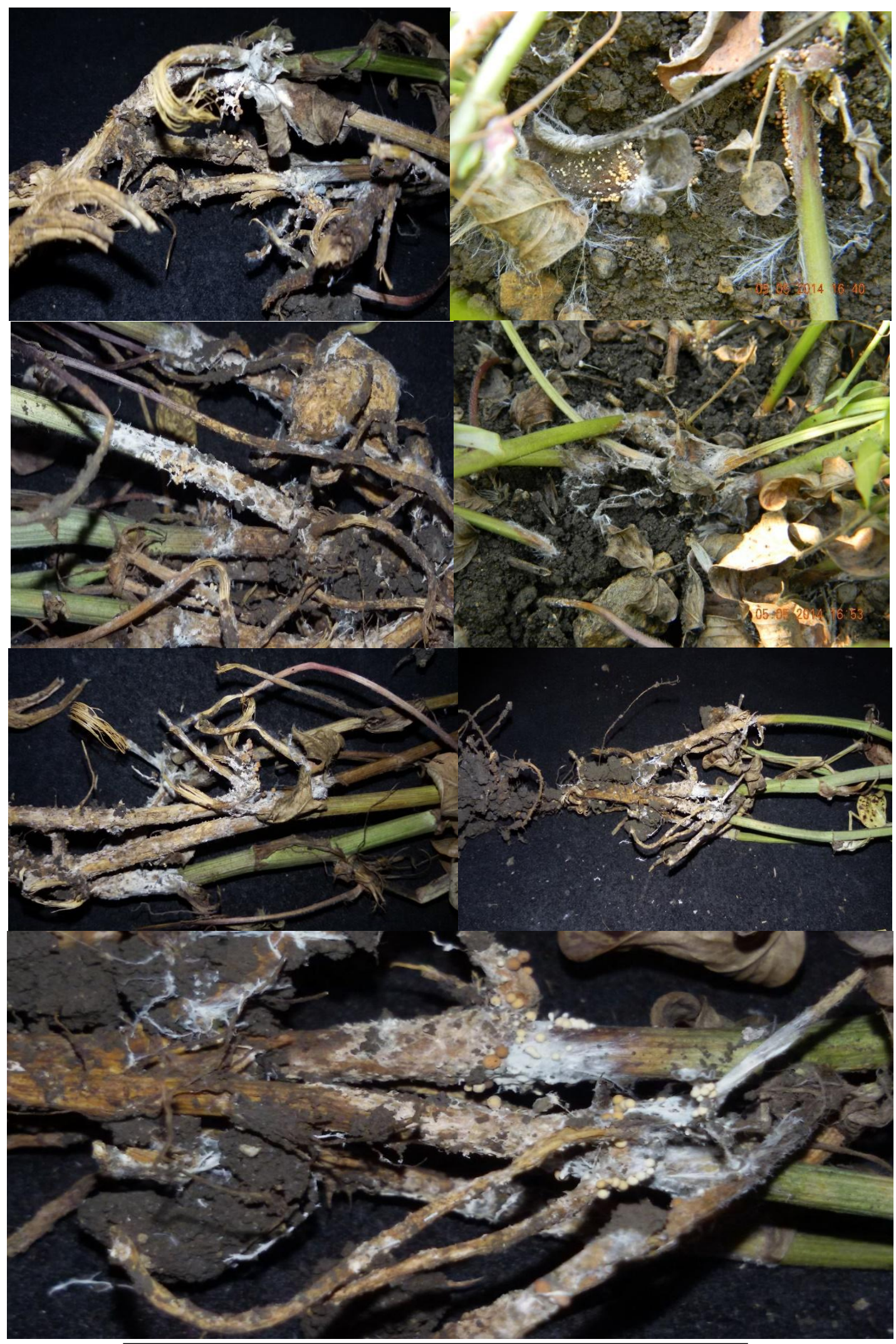

Photo Plate 1: Stem Rot Disease of Ground nut 


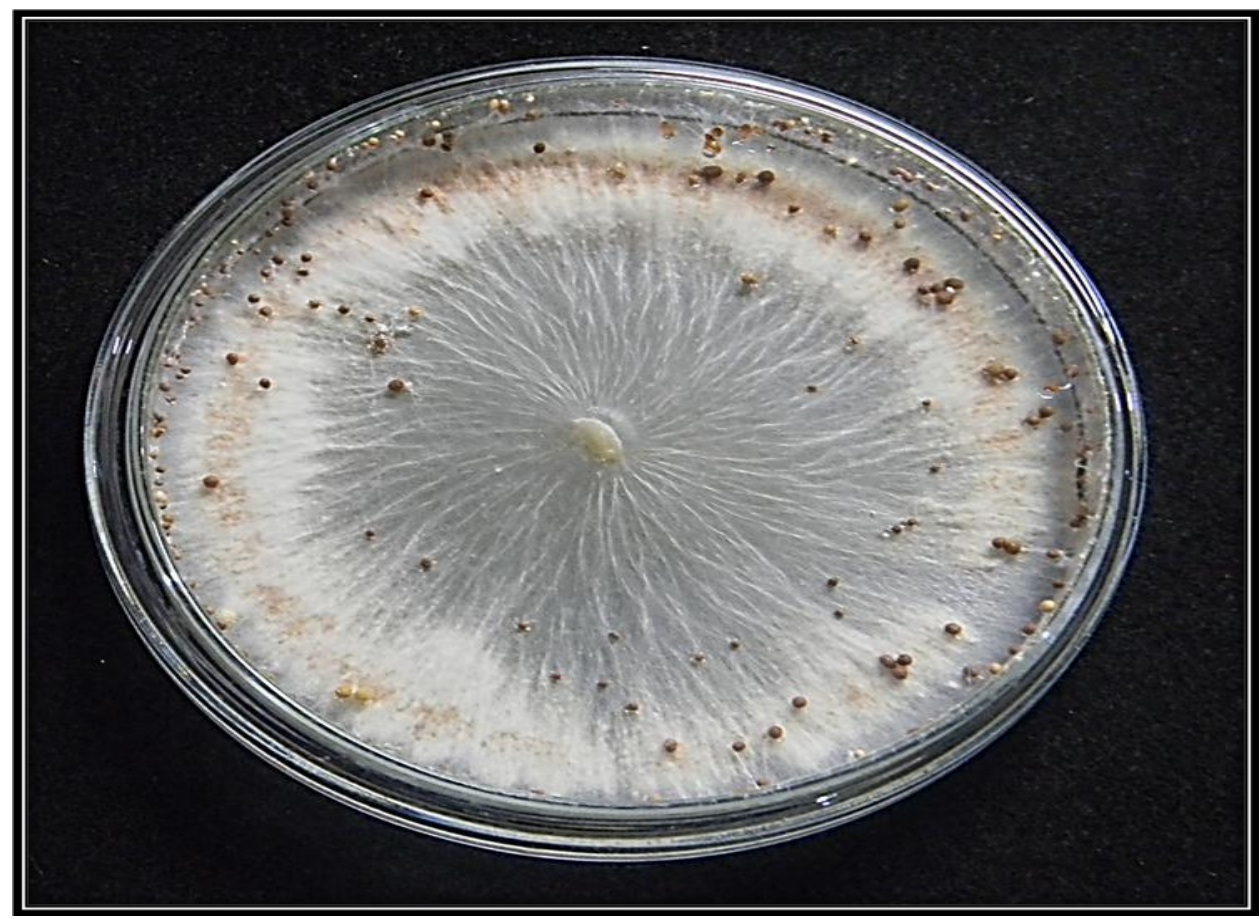

Photo Plate 2: Isolation of Sclerotium rolfsii from Infected Groundnut Stem

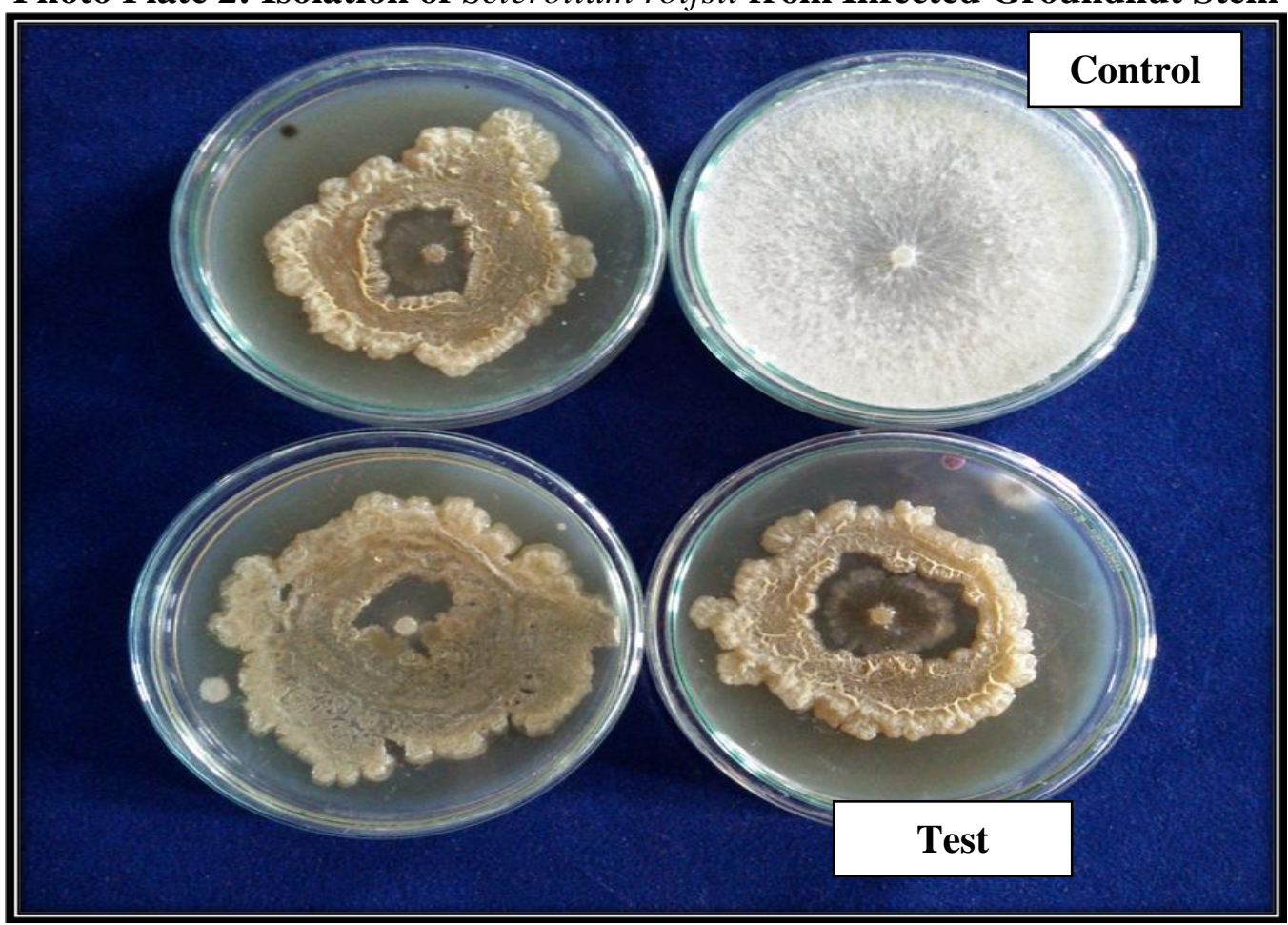

Photo Plate 3: Antagonism of Bacillus thuringiensis NCIM2130 against Sclerotium rolfsii by Novel Ring method (Secondary Screening) 


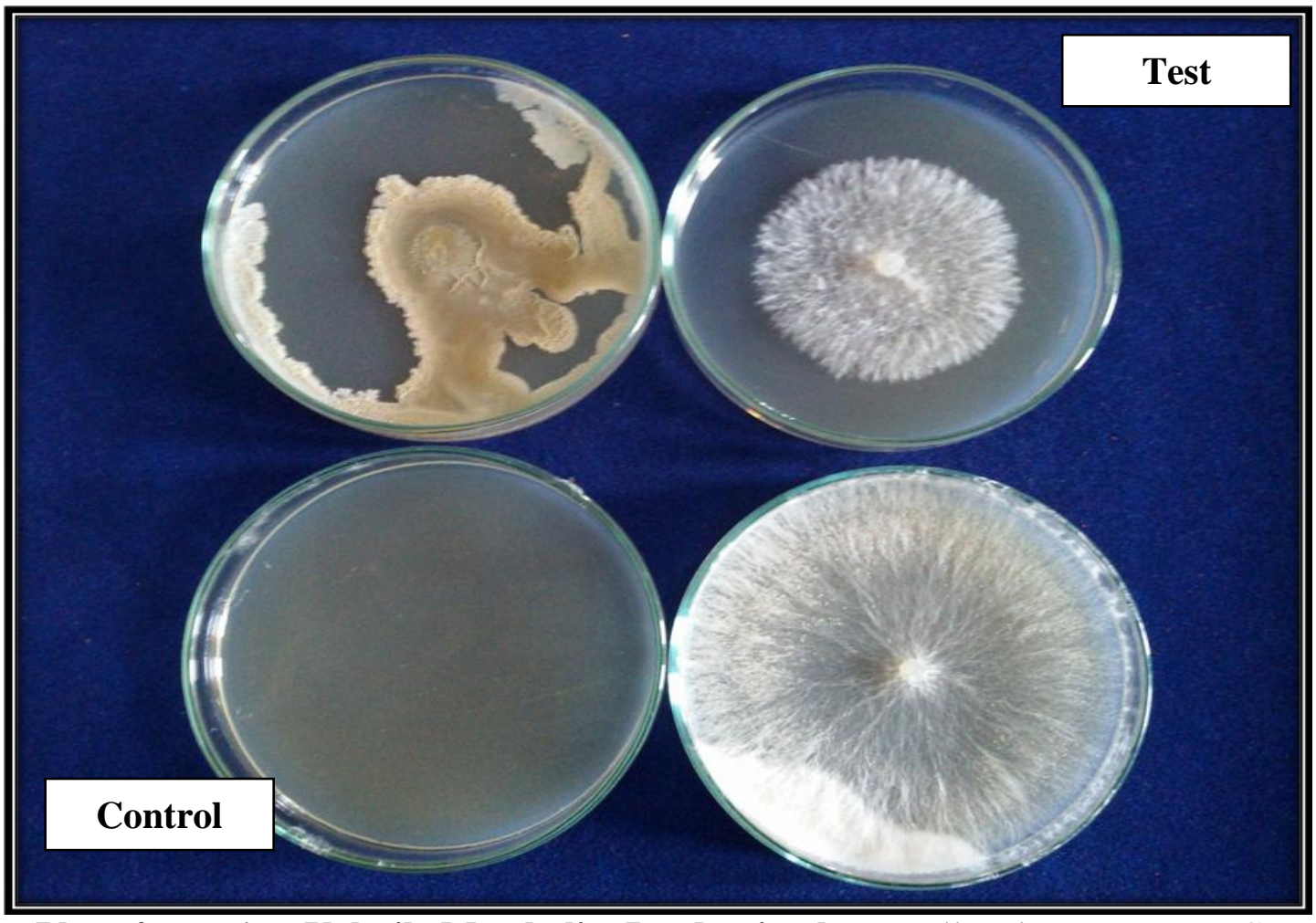

Photo Plate 4: In Vitro Volatile Metabolite Production by Bacillus thuringiensis NCIM2130

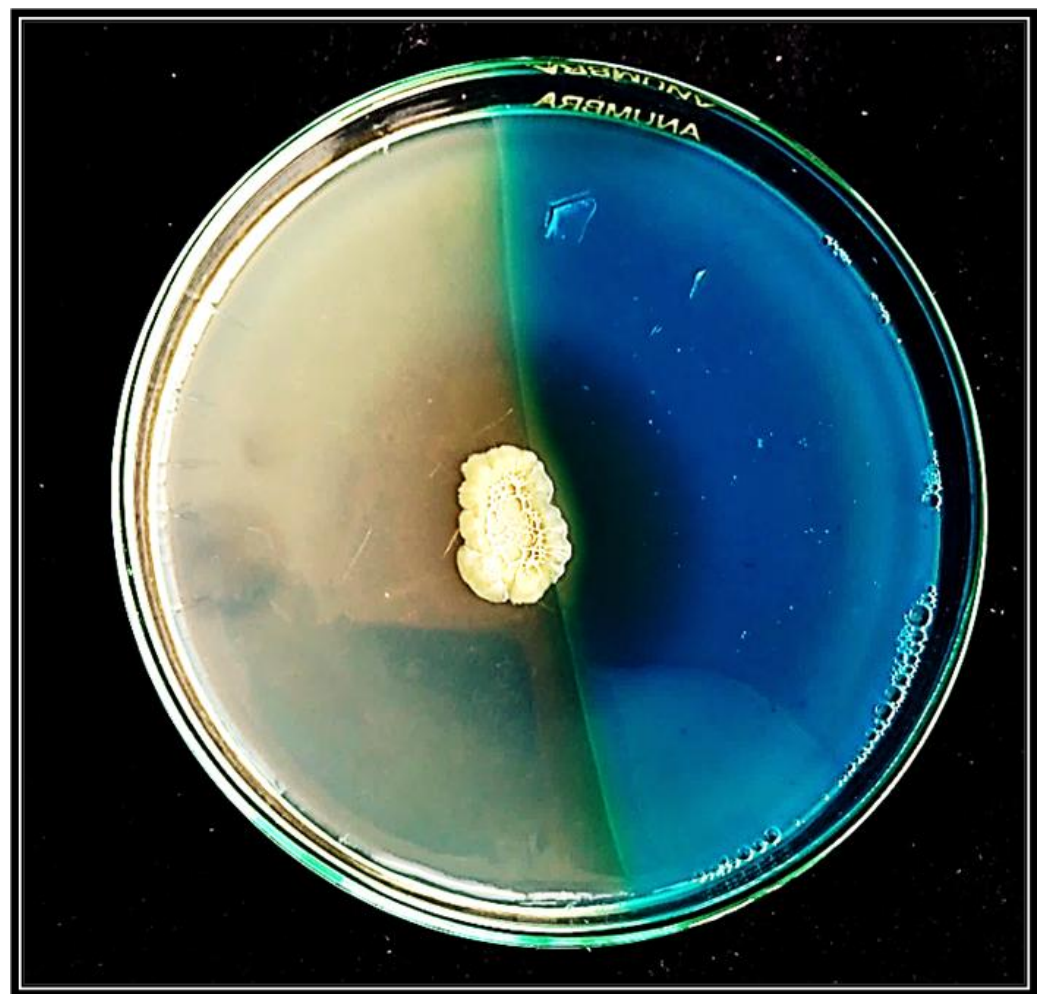

Photo plate 5: Agar plate containing CAS - blue agar and Nutrient Agar inoculated with Bacillus thuringiensis NCIM2130 
Table.2 Secondary screening of efficient Bacillus isolate against Sclerotium rolfsii by Novel Ring

\begin{tabular}{|l|c|c|c|}
\hline Bacterial culture & $\begin{array}{l}\text { Test (Growth of fungal } \\
\text { pathogen with } \\
\text { culture in mm) }\end{array}$ & $\begin{array}{l}\text { Control (Growth of fungal } \\
\text { bacterial } \\
\text { pathogen with out bacterial } \\
\text { culture in mm) }\end{array}$ & Pent Inhibition\% \\
\cline { 1 - 3 } $\begin{array}{l}\text { Bacillus } \\
\text { thuringiensis }\end{array}$ & 24 & 92 & \multirow{2}{*}{$\mathbf{8 0 . 2 1}$} \\
\cline { 2 - 3 } NCIM2130 & 20 & 91 & \\
\cline { 2 - 3 } Average & 10 & 90 & \\
\hline
\end{tabular}

Antibiosis mediated by volatile substances has received less attention than antibiosis through the production of non-volatile antibiotics or siderophores. Hydrogen cyanide $(\mathrm{HCN})$ effectively blocks the cytochrome oxidase pathway and is highly toxic to all aerobic microorganisms at picomolar concentrations. The production of $\mathrm{HCN}$ by certain fluorescent pseudomonads is believed to be involved in the suppression of root pathogens. P. fluorescens CHAO produces antibiotics, siderophores and $\mathrm{HCN}$, but suppression of black rot of tobacco caused by Thielaviopsis basicola appeared to be due to HCN production (Voisard et al., 1989). Enterobacter cloacae reported to produce a volatile compound such as ammonia to suppression the growth of Pythium ultimum-induced damping-off of cotton (Howell et al., 1988). These results suggest that Bacillus thuringiensis NCIM2130 produced some volatile compound to inhibit Sclerotium rolfsii.

\section{Qualitative Detection of Siderophore}

The universal CAS assay was used form detection of siderophore production by different microorganisms in solid medium (Schwyn and Neilands, 1997) When CAS Agar plates were prepared according to Schwyn and Neilands used for detection of siderophore, most of fungi and bacteria mainly Gram positive did not grow. As stated in literature, this problem which is caused by the toxicity of HDTMA present in CAS Agar plates, affects mainly fungi and Gram positive bacteria.
When modified CAS - blue Agar plates were prepared as per (Adriane et al.,1999) used for detection of siderophore, Bacillus thuringiensis NCIM2130 grew rapidly in Nutrient agar plate, half containing medium but did not grow at all in the plate - half containing the CAS agar. The siderophore type compounds were excreted by Bacillus thuringiensis NCIM2130 and diffused through the CAS - blue agar, producing a colour change from blue to orange as shown in photo plate 5. For Bacillus thuringiensis NCIM2130 the colour change started after the Bacillus thuringiensis NCIM2130 had covered the plate halves containing the King's B medium for the growth (Schwyn and Neilands, 1997; Payne, 1994). This result reveals that modified CAS - blue agar found effective in qualitative detection of siderophore.

In conclusion, during this study, among 120 the bacillus spp. screened as biocontrol agent against Sclerotium rolfsii, Bacillus thuringiensis NCIM2130 was found effective in controlling the phytopathogenin vitro. This proves that the rhizospheric bacillus can be exploited as good biocontrol agent and can be tested in vivo in pot assay.

\section{Acknowledgment}

The author is grateful for the financial support provided by University Grants Commission, New Delhi, as Major Research Project grant. 


\section{References}

Adetuyi, F.C., and Cartwright D.W. 1985. Studies on the antagonistic activity of bacteria endemic on cereal seed. I Quantification of antagonists activity. Ann. Appl. Biol., 107: 33 - 43.

Adriane M.F., Milagres, Angela Machuca, and Diovana Napolea o. 1999. Detection of siderophore production from several fungi and bacteria by a modification of chrome azurol $\mathrm{S}$ (CAS) agar plate assay, J. Microbiol. Methods, 37: pp. $1-6$.

Agarry, O.O., Akinyosoye, F.A., and Adetuyi, F.C. 2005. Antagonistic properties of microorganisms associated with cassava (Manihot esculenta Crantz) products. African J. Biotechnol., Vol. 4 (7): pp. 627-632.

Beneduzi, A., Peres, D., Costa, B.P.Z., Anettini, M.H.B., and Passaglia, L.M.P. 2008. Genetic and phenotypic diversity of plant growth promoting Bacilli isolated from wheat fields in southern. Brazilian Res. Microbiol., 159: $244-250$.

Calvo, P., Ormeno, O.E., Martinez, R.E., and Zuniga, D. 2010. Characterization of Bacillus isolates of potato rhizosphere from andean soils of Peru and their potential PGPR characteristics. Brazilian J. Microbiol., 41: 899-906.

Claus, D., and Berkeley, R.C.W. 1986. Genus Bacillus Cohn. 1872. In: Sneath, P.H.A. (Ed.). Bergey's Manual of Systematic Bacteriology. Williams and Wilkins Co., Baltimore, MD, USA. Section 13(2), 1105-1139.

Erturk, Y., Ercisli, S., Haznedar, A., Cakmakci, R. 2010. Effects of plant growth promoting rhizobacteria (PGPR) on rooting and root growth of kiwifruit Actinidia deliciosa stem cuttings. Biol. Res., 43: 91 - 98.
Ferreira, J.H., Matthee, F.N., and Thomas, A.C. 1991. Biological control of Eutypa lata on grapevine by an antagonistic strain of Bacillus subtilis. Phytopathol., 81: 283 -287.

Franks, A., Ryan, R.P., Abbas, A., Mark, G.L., and Gara, F. 2006. Molecular tools for studying plant growth promoting rhizobacteria (PGPR). In. Molecular techniques for soil and rhizosphere microorganisms. CABI Publishing, Wallingford, Oxfordshire, UK.

Gajbhiye, A., Alok, R.R., Sudhir, U.M., Dongre, A.B. 2010. Isolation, evaluation and characterization of Bacillus subtilis from cotton rhizospheric soil with biocontrol activity against Fusarium oxysporum. World J. Microbiol. Biotechnol., 26: 1187-1194.

Gomashe Ashok, V., Sheikh Neha, A.M. and Gulhane Pranita, A. 2014. Production of Bioactive Compound by Bacillus subtilis and its antagonistic activity against Sclerotium rolfsii. Int. J. Life Sci., Vol. 2(2): 127 - 133.

Govindasamy, V., Senthilkumar, M., Magheshwaran, V., Kumar, U., Bose, P., Sharma, V., Annapurna, K. 2011. Bacillus and Paenibacillus spp. Potential PGPR for sustainable agriculture. Plant Growth and Health Promoting Bacteria (Microbiology Monographs) 18, 333-364.

Helena, A., Keyser and J.H.S. Ferreira. 1988. Chemical and Biological Control of Sclerotium rolfsii in Grapevine Nurseries. S. Afr. J. Enol. Vitic., Vol 9 No.1 pp 43 - 44.

Howell, C.R., Beier, R.C., and Stipanovic, R.D. 1988. Production of ammonia by Enterobacter cloacae and its possible role in the biological control of Pythium preemergence damping-off 
by the bacterium. Phytopathol., 78: 1075-1078.

Idris, E.E.S., Iglesias, D., Talon, M., Borriss, R. 2007a. Tryptophan dependent production of indole-3-acetic acid (IAA) affects level of plant growth promotion by Bacillus amyloliquefaciens FZB42. Molecular Plant Microbe Interaction, 20: 619626.

Idris, H.A., Labuschagne, N., Korsten, L. 2007b. Screening rhizobacteria for biological control of Fusarium root and crown rot of sorghum in Ethiopia. Biol. Control, 40(1): 97-106.

Karimi, K., J. Amini, B. Harighi, B. Bahramnejad 2012. Evaluation of biocontrol potential of Pseudomonas and Bacillus spp. against Fusarium wilt of chickpea. Australian J. Crop Sci., 6(4): $695-703$.

Illani, A.S., Abaidoo, R. C., Akintokun, A. K., and Abiala, M.A. 2011. Antagonistic Effect of Indigenous Bacillus subtilis on Root-/Soil-borne Fungal Pathogens of Cowpea. Researcher, 3(3), pp. $11-18$.

Kim, D.S., R.J. Cook, and D.M. Weller 1997. Bacillus sp.L324-92 for biological control of three root diseases of wheat grown with reduced tillage. Phytopathol., 87: 551-558.

Kloepper, J.W., Ryu, C.M., Zhang S.2004. Induced systemic resistance and promotion of plant growth by Bacillus sp. Phytopathol., 94: 1259-1266.

Liu, Y.F., Chen, Z.Y., Nag, T.B., Zhang, J., Zhou, M.G., Song, F.P., and Liu, Y.Z.2006. Bacisubin, an antifungal protein with ribonuclease and hem agglutinating activities from Bacillus subtilis strain B-916. Peptides, 28: 553-559.

Mesquita, E.R., O.L. Pereira, and J.A.S. Grossi. 2007. Basal rot of arum lily (Zantedeschia aethiopica) caused by
Sclerotium rolfsii in Brazil. Australasian Plant Disease Notes, 2; 91-92.

Montealegro, J.R., Reyes, R., Perez, R., Herrera, L.M., Silva, P. and Besoain, X. 2003. Selection of bioantagonistic bacteria to be used in biological control of Rhizoctonia solani in tomato. J. Biotechnol., 6: 115-127.

Nalisha I., M. Muskhazli, and T. Nor Farizan. 2006. Production of bioactive compounds by Bacillus subtilis against Sclerotium rolfsii. Malays. J. Microbiol., vol. 2, no. 2, pp. $19-23$.

Pande, S. and J.Narayana Rao. 2000. Changing scenario of groundnut diseases in AndhraPradesh, Karnataka and TamilNadu states of India. International Arachis News letter, 20:42-44.

Payne, S.M. 1994. Detection, isolation, and characterization of siderophore. Methods Enzymol., 235: 329 - 344.

Rakh, R.R. 2010. Investigation on Biological Control of Major Groundnut (Arachis hypogaea Linn.) Diseases, A Ph.D. thesis submitted to S. R. T. M. University, Nanded.

Ran L.X., Xiang, M.L., Van Loon, L.C. and Bakker, P.A.H.M. 2003. Siderophoremediated suppression of Grey Mould in Eucalyptus urophylla by Fluorescent Pseudomonas spp. 6th International PGPR Workshop, 5-10 October 2003, Calcutta, India. 558562.

Rangeshwaran, R. and Prasad, R.D. 2000. Biological control of Sclerotium rot of sunflower. Indian Phytopathol., 53: 444-449.

Riungu, G.M., J.W. Muthorni, R.D. Narla, J. M. Wagacha and J.K. Gathumbi 2008. Management of Fusarium Head Blight of Wheat and Deoxynivalenol Accumulation using Antagonistic 
Microorganisms. Plant Pathol. J., 7(1): $13-19$.

Schwyn, B., and Neilands, J.B. 1997. Universal chemical assay for the detection and determination of siderophores. Anal. Bio- and chem., 160, 46-56.

Thilagavathi Rasu, Nakkeeran Sevugapperumal, Raguchander Thiruvengadam and Samiyappan Ramasamy. 2013. Biological Control of Sugarbeet Root Rot Caused by Sclerotium rolfsii. Int. J. Biol. Ecol. Environ. Sci., Vol. 2, No. 1, 2277 4394.

Viruel, E., Lucca, M.E., and Sineriz, F. 2011. Plant growth promotion traits of phosphobacteria isolated from puna,
Argentina. Arch. Microbiol., 193: 489496.

Voisard, C., Keel, C., Haas, D., and Defago, G. 1989. Cyanide production by Pseudomonas fluorescens helps suppress black root rot of tobacco under gnotobiotic conditions. $E M B O$. J., 8: 351-358.

Wahyudi A.T., R.P. Astuti, A. Widyawati, A. Meryandini, and A.A. Nawangsih 2011. Characterization of Bacillus sp. strains isolated from rhizosphere of soybean plants for their use as potential plant growth for promoting Rhizobacteria. J. Microbiol. Antimicrobials, vol. 3, no. 2, pp. 34 40.

\section{How to cite this article:}

Ravindra Raosaheb Rakh and Sanjay Marotrao Dalvi. 2016. Antagonism of Bacillus thuringiensis NCIM2130 against Sclerotium rolfsii Sacc., A Stem Rot Pathogen of Groundnut. Int.J.Curr.Microbiol.App.Sci. 5(8): 501-513. doi: http://dx.doi.org/10.20546/ijcmas.2016.508.054 